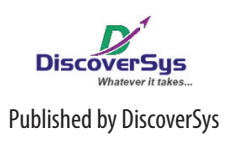

Published by Discoversys

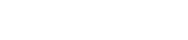

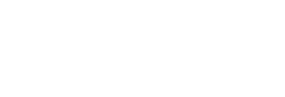

(1)

'Bali Health Institute,

${ }^{2}$ Department of Public Health and Preventive Medicine, Faculty of Medicine, Udayana University,

${ }^{3}$ Department of Psychology, Faculty of Medicine, Udayana University

*Correspondence to:

Putu Noviana Sagitarini, Bali Health Institute

sagitarini.novi@gmail.com

\title{
Association between emotional regulation and family support with quality of life of women with cervical cancer
}

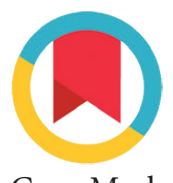

CrossMark

\author{
Putu Noviana Sagitarini, ${ }^{1 *}$ Putu Cintya Denny Yuliyatni, ${ }^{2}$ Ni Made Swasti Wulanyani ${ }^{3}$
}

\section{ABSTRACT}

Background and purpose: Cervical cancer ranks third globally and ranks second in Indonesia for all cancers in women. Women with cervical cancer experience physical and psychological disorders that can affect their quality of life. This study aims to determine the association between emotional regulation and family support with the quality of life of women with cervical cancer.

Methods: A cross sectional survey was conducted in April 2018 at the Sanglah Hospital Obstetric Clinic. The study samples were chosen consecutively and consisted of 100 women with cervical cancer who underwent outpatient care. Data was collected using questionnaires filled in by the respondents and from the patient's medical records.
Bivariate analysis was conducted with chi square test and multivariate with logistic regression.

Results: The results showed that emotional regulation and family support were found to be significantly related to the quality of life of women with cervical cancer, each with $A 0 R=17.64 ; 95 \% \mathrm{Cl}$ : 3.01-103.46; $p=0.001$ and $A O R=11.28 ; 95 \% \mathrm{Cl}$ : 1.88-67.78; $\mathrm{p}=0.008$.

Conclusion: Emotional regulation and family support are related to the quality of life of women with cervical cancer. Efforts to improve emotional regulation and family support for patients should be carried out to improve their quality of life.

Keywords: emotional regulation, family support, quality of life, cervical cancer

Cite This Article: Sagitarini, P.N., Yuliyatni, P.C.D., Wulanyani, N.M.S. 2019. Association between emotional regulation and family support with quality of life of women with cervical cancer. Public Health and Preventive Medicine Archive 7(1):32-37. D01:10.15562/phpma.v7i1.191

\section{INTRODUCTION}

Cervical cancer ranks third in the world of all cancers experienced by women. ${ }^{1}$ In 2018 , the incidence of cervical cancer globally was estimated at 570,000 new cases or $6.6 \%$ of all female cancers. ${ }^{2}$ About $90 \%$ of deaths from cervical cancer occur in low and middle income countries. ${ }^{2}$ In Indonesia, the incidence of cervical cancer is still the second highest after breast cancer. In 2018, an estimated 32 thousand women were diagnosed and 18 thousand died from cervical cancer. Based on the calculation of the age standardized rate (ASR), the incidence of cervical cancer in Indonesia is estimated to reach 23.4 per 100,000 women per year with a mortality rate of 13.9 per 100,000 , which is higher than global incidence of 13.1 per 100,000 and mortality of 6.9 per $100,000 .^{1}$

Women with cervical cancer experience physical, psychological and social problems due to illness or therapy that can lead to a decrease in their quality of life. ${ }^{3}$ Understanding the factors that affect the quality of life of women with cervical cancer is important for the development of interventions or services to achieve better outcomes. ${ }^{4}$

Several studies carried out in Indonesia and other countries among non-cancer patients show that a person's quality of life is influenced by emotional regulation. ${ }^{5,6}$ Emotional regulation is a person's ability to manage emotions so that they do not further suffer when experiencing problems, and this has very important implications for health especially in individuals with chronic diseases. ${ }^{7}$ In addition, other studies conducted in Indonesia, Slovakia, Turkey and China show that the quality of life of cancer patients is influenced by family support. $^{8-11}$

The studies related to the quality of life of patients with cervical cancer that have been carried out in Indonesia use more qualitative and quantitative methods with descriptive designs. ${ }^{3,4,8}$ In qualitative studies, factors that affect quality of life can be explored but the magnitude of their contribution to quality of life cannot be measured. This study employed a quantitative analytic design and aims to determine the association between emotional regulation and family support with the quality of life of women with cervical cancer.

\section{METHODS}

A cross sectional survey was conducted at the Obstetric Polyclinic, Sanglah General Hospital, Denpasar. Sanglah Hospital is the main referral hospital for Bali, West and East Nusa Tenggara. The Obstetric and Gynecology Polyclinic of Sanglah 
Hospital has a high number of cervical cancer patient visits, reaching 5,277 in $2016 .{ }^{12}$

The study samples were recruited with consecutive sampling, consisted of 100 cervical cancer patients underwent outpatient care. Sample size was determined with 95\% confidence level, $80 \%$ power, proportion of cervical cancer patients with good family support and high quality of life $=0.864$, proportion of cervical cancer patients with poor family support and high quality of life $=0.438 .{ }^{13}$ Respondent eligibility criteria was being able to communicate verbally and in writing until the data collection phase ends. Data collection was conducted over April 23-30, 2018 with a self-administered questionnaire and accompanied by researchers. Data on disease history and treatment of respondents was obtained from the patient's medical records. The questionnaire consists of socio-demographic characteristics, emotional regulation, family support and quality of life.

The emotional regulation questionnaire consisted of 20 statements that refer to the Theory of Emotion Regulation according to Gross \& John which consists of situation selection, modification of the situation, deployment of attention, cognitive change and response modulation. ${ }^{14}$ The family support questionnaire consisted of 16 statements that refer to Friedman's Family Support Theory, which included emotional, assessment, instrumental and informational supports. ${ }^{15}$ Variables of quality of life were measured with the European Organization for Research and Treatment of Cancer Quality of Life Questionnaire-C-30 (EORTC QLQ C-30), a questionnaire used to assess the quality of life of cancer patients. Measurement of quality of life consisted of three aspects, namely global health status, function and symptom scales, which consisted of 30 statements. All questionnaires were translated into Indonesian and pre-tested to some cervical cancer outpatients before the data collection was conducted.

Global health status is the subjective assessment of the respondent's overall quality of life. Function scales consist of physical, role, emotional, cognitive and social functions. While symptom scales consist of fatigue, nausea and vomiting, pain, shortness of breath, difficulty in sleeping, loss of appetite, constipation, diarrhea and financial difficulties. ${ }^{16}$ Each statement on emotional regulation consists of four choices of answers that are "strongly disagree" which scored of 1, "disagree" of 2, "agree" of 3 and "strongly agree" of 4 . Likewise each statement for family support consists of four choices of answers that are "never" which scored of 1 , "rare" of 2 , "often" of 3 , and "always" of 4.

The score of each item for each variable was summed so that the total score for each part was obtained, namely the total scores of quality of life, emotion regulation and family support. Furthermore, the total score of each variable was grouped into two categories based on the median value. Emotional regulation and quality of life were categorized as "high" if the score was more or equal to median and "low" if the score was less than median. Family support was categorized "high" if the score was more or equal to median and "low" if the score was less than median.

The association between emotional regulation and family support with quality of life was assessed through bivariate analysis with chi square test. Variables in bivariate analysis that had a p value of $<0.25$ were included in the model in multivariate analysis carried out with logistic regression. This study has been approved by the Ethics Committee of Faculty of Medicine, Udayana University/ Sanglah General Hospital on April 11, 2018.

\section{RESULTS}

The socio-demographic characteristics, disease history and treatment of respondents are presented in Table 1. Respondents in this study were 25 to 69 years old, with an average age of 49 years. As many as $61 \%$ completed elementary or junior high education and 52\% worked (farmers, traders, laborers, employees) while the rest were unemployed. Based on the history of the disease, respondents were diagnosed with cervical cancer for 1 to 36 months (mean=10 months) up to the time of data collection. As many as $46 \%$ of respondents suffered from Stage II cervical cancer, more than $90 \%$ of respondents were undergoing chemotherapy and regularly sought outpatient care at the hospital.

Table 2 presents the proportion, mean and median score of emotion regulation, family support and quality of life. The median value of the respondent's quality of life was 113 (55\% were above median), emotional regulation was 69 (51\% were above median) and family support was 58.5 (50\% were above median).

Table 3 presents the association between respondents' characteristics, emotion regulation and family support with quality of life. It shows that quality of life was associated with emotional regulation $(p<0.01)$ and family support $(\mathrm{p}<0.01)$.

Table 4 shows the results of multivariate analysis with logistic regression between emotional regulation variables and family support with quality of life, and it appears that emotional regulation and family support are significantly related to quality of life, each with AOR=17.64 (95\%CI: 3.01-103.46; $\mathrm{p}<0.01)$ and $\mathrm{AOR}=11.28 \quad(95 \% \mathrm{CI}: \quad 1.88-67.78$; $\mathrm{p}<0.01)$. 
Table 1 Socio-demographic characteristics of respondents, disease history and treatment

\begin{tabular}{|c|c|c|}
\hline Variables & $\mathbf{n}$ & $\%$ \\
\hline \multicolumn{3}{|l|}{ Age (years) } \\
\hline$<49$ & 48 & 48.0 \\
\hline$\geq 49$ & 52 & 52.0 \\
\hline \multicolumn{3}{|l|}{ Education } \\
\hline Elementary/junior high & 61 & 61.0 \\
\hline Senior high & 29 & 29.0 \\
\hline Tertiary (diploma/bachelor) & 10 & 10.0 \\
\hline \multicolumn{3}{|l|}{ Employment } \\
\hline Employed & 52 & 52.0 \\
\hline Unemployed & 48 & 48.0 \\
\hline \multicolumn{3}{|l|}{ Cancer stadium } \\
\hline I & 25 & 25.0 \\
\hline II & 46 & 46.0 \\
\hline III & 27 & 27.0 \\
\hline IV & 2 & 2.0 \\
\hline \multicolumn{3}{|c|}{ Period of cancer diagnosis (months) } \\
\hline$<10$ & 61 & 61.0 \\
\hline$\geq 10$ & 39 & 39.0 \\
\hline \multicolumn{3}{|l|}{ Therapy } \\
\hline Surgery & 5 & 5.0 \\
\hline Radiotherapy & 4 & 4.0 \\
\hline Chemotherapy & 91 & 91.0 \\
\hline \multicolumn{3}{|l|}{ Adherence to therapy } \\
\hline High & 97 & 97.0 \\
\hline Low & 3 & 3.0 \\
\hline Total & 100 & 100.0 \\
\hline
\end{tabular}

Table 2 Proportion, mean and median score of emotion regulation, family support and quality of life

\begin{tabular}{|c|c|c|c|c|c|}
\hline Variables & n (\%) & Mean (SD) & Median & Min & Max \\
\hline Emotional regulation & & $67.9(7.7)$ & 69.0 & 54 & 80 \\
\hline High & $51(51.0)$ & & & & \\
\hline Low & $49(49.0)$ & & & & \\
\hline Family support & & $55.5(7.4)$ & 58.5 & 41 & 64 \\
\hline High & $50(50.0)$ & & & & \\
\hline Low & $50(50.0)$ & & & & \\
\hline Quality of life & & $109.2(8.6)$ & 113.0 & 73 & 120 \\
\hline High & $55(55.0)$ & & & & \\
\hline Low & $45(45.0)$ & & & & \\
\hline
\end{tabular}

\section{DISCUSSION}

The proportion of women with cervical cancer who have a quality of life above the median value in this study is $55 \%$. This study indicates that emotional regulation and family support are significantly related to the quality of life of cervical cancer patients, where emotional regulation AOR is found to be higher than AOR of family support. This shows that internal factors (emotional regulation) 
Table 3 Association between respondents' characteristics, emotional regulation and family support with quality of life

\begin{tabular}{|c|c|c|c|}
\hline \multirow[b]{2}{*}{ Variable } & \multicolumn{2}{|c|}{ Quality of life } & \multirow[b]{2}{*}{$\mathbf{p}$} \\
\hline & $\begin{array}{l}\text { High } \\
\text { n (\%) }\end{array}$ & $\begin{array}{l}\text { Low } \\
\text { n (\%) }\end{array}$ & \\
\hline Age (years) & & & 0.81 \\
\hline$<49$ & $27(56.2)$ & $21(43.8)$ & \\
\hline$\geq 49$ & $28(53.8)$ & $24(46.2)$ & \\
\hline Education & & & 0.57 \\
\hline Elementary/junior high & $31(50.8)$ & $30(49.2)$ & \\
\hline Senior high & $18(62.1)$ & $11(37.9)$ & \\
\hline Tertiary (diploma/bachelor) & $6(60.0)$ & $4(40.0)$ & \\
\hline Employment & & & 0.52 \\
\hline Employed & $27(51.9)$ & $25(48.1)$ & \\
\hline Unemployed & $28(58.3)$ & $20(41.7)$ & \\
\hline Cancer stadium & & & 0.21 \\
\hline I & $11(44.0)$ & $14(56.0)$ & \\
\hline II & $28(60.9)$ & $18(39.1)$ & \\
\hline III & $16(59.3)$ & $11(40.7)$ & \\
\hline IV & $0(0)$ & $2(100)$ & \\
\hline Period of cancer diagnosis (months) & & & 0.55 \\
\hline$<10$ & $35(57.4)$ & $26(42.6)$ & \\
\hline$\geq 10$ & $20(51.3)$ & $19(48.7)$ & \\
\hline Therapy & & & 0.69 \\
\hline Surgery & $3(60.0)$ & $2(40.0)$ & \\
\hline Radiotherapy & $3(75.0)$ & $1(25.0)$ & \\
\hline Chemotherapy & $49(53.8)$ & $42(46.2)$ & \\
\hline Adherence to therapy & & & 0.59 \\
\hline High & $54(55.7)$ & $43(44.3)$ & \\
\hline Low & $1(33.3)$ & $2(66.7)$ & \\
\hline Emotional regulation & & & $<0.01$ \\
\hline High & $48(94.1)$ & $3(5.9)$ & \\
\hline Low & $7(14.3)$ & $42(85.7)$ & \\
\hline Family support & & & $<0.01$ \\
\hline High & $47(94.0)$ & $3(6.0)$ & \\
\hline Low & $8(16.0)$ & $42(84.0)$ & \\
\hline
\end{tabular}

Table 4 Adjusted odd ratio of emotion regulation and family support with quality of life

\begin{tabular}{lcccc}
\hline & & \multicolumn{2}{c}{$\mathbf{9 5 \% \mathrm { Cl }}$} & $\mathbf{p}$ \\
\cline { 3 - 4 } Variable & AOR & Lower & Upper & \\
\hline $\begin{array}{l}\text { Emotional regulation } \\
\text { Low }\end{array}$ & 1 & & & \\
$\quad$ High & 17.64 & 3.01 & 103.46 & $<0.01$ \\
$\begin{array}{l}\text { Family support } \\
\text { Low }\end{array}$ & 1 & & & \\
High & 11.28 & 1.88 & 67.78 & $<0.01$ \\
\hline
\end{tabular}


are more dominant than external factors (family support) in influencing quality of life. A woman diagnosed with cervical cancer will go through five stages of emotional regulation until they can accept the changes in herself. The stages are situation selection, situation modification, open attention, cognitive changes and response adjustments. ${ }^{14}$ In this study the ability of a person to regulate her emotion will likely affect the success of self-adjustment to all situations. The success of this self-adjustment will be one of the factors that influence her quality of life. Emotional regulation as an internal factor in this study also has a more dominant role than the external factors. This finding shows that individual factors determine a person's quality of life more than external factors although they cannot be ignored.

The results of our study are similar with the results of other studies conducted in Indonesia and other countries with different study design and disease of interest. A study conducted in Indonesia states that there is an influence of emotional regulation on improving the quality of life of patients with chronic diseases ${ }^{6}$ and a study conducted in India states that there is a significant association between regulation of emotions and the quality of one's life. ${ }^{5}$ A qualitative study conducted in Jakarta shows that cervical cancer and its treatment have emotional consequences related to chronic conditions that they experience and can have a psychological impact on women who have undergone cervical cancer therapy. ${ }^{17}$ The results of other qualitative studies conducted in Surabaya state that most women who suffer from cervical cancer feel themselves in a crisis period that requires adjustment. ${ }^{8}$ In this study, it was explained that each individual will need different adjustments depending on self-acceptance or ability to control emotions towards changes that occur and will affect the quality of life. ${ }^{8}$ Regarding family support, the findings of our study are in accordance with the theory introduced by Friedman, et al., which states that family support is very important for someone suffering from an illness, where the family can provide emotional, assessment, instrumental and information supports. ${ }^{15}$ In the Indonesian community, a family as the closest social environment significantly influences an individual decision making process and the other life aspects. Families, in this study, also shown to be an influential factor for the level of quality of life.

Our study findings are also similar with other studies conducted in surgical inpatient care at Dr. Mohammad Hoesin Hospital, Palembang, where it was discovered that there was an association between family support and the quality of life for cancer patients. ${ }^{18}$ Another study conducted in Henan, China also stated that there was an association between social support and the quality of life of cancer patients. ${ }^{11}$ A qualitative study conducted in Jakarta found that social support greatly influences psychosocial changes in women with cervical cancer. ${ }^{17}$ It is explained that the ability and presence of people who are significant in the phase of diagnosis and therapy can significantly affect women's views of themselves and coping ability when facing the disease. ${ }^{17}$

Our findings have practical implications that the treatment of cervical cancer patients should not only focus on the physical condition of the patient, but also on the psychological and social aspects of the patient. However, there are several limitations which need to be considered. All questionnaires have been pre-tested however they were not validated. The samples of our study were selected consecutively which may lead to a selection bias in terms of socio-demographics of the samples and cancer stage and treatment. In addition, there might be some confounding factors which not explored in our study, such as mental health status and spiritual wellbeing of the patients. ${ }^{19,20}$ Our study was conducted at Sanglah General Hospital Denpasar, which is a government hospital, so that our findings cannot be generalized to cervical cancer patients seeking treatment at private hospitals as there are likely different characteristics of patients such as the socioeconomic conditions. In addition, neither can be generalized to all women with cervical cancer because the subjects of this study were only those who were undergoing outpatient care in the hospital. The different physical condition of those undergoing inpatient care might influence their ability to fill in the questionnaires.

\section{CONCLUSION}

Emotional regulation and family support have a significant association towards the quality of life of women with cervical cancer. Efforts to improve emotional regulation capabilities and increase family involvement in providing care for women with cervical cancer needs to be done to increase their quality of life.

\section{ACKNOWLEDGEMENT}

We would like to thank the Director and staff at the Obstetric Polyclinic of Sanglah General Hospital, Denpasar, as well as all respondents who have participated in this study.

\section{REFERENCES}

1. Bruni L, Albero G, Serrano B, Mena M, Gómez D, Muñoz J, Bosch FX, de Sanjosé S. ICO/IARC Information Centre on HPV and Cancer (HPV Information Centre). Human Papillomavirus and Related Diseases in Indonesia. Summary Report 10 December 2018 
2. WHO. Cervical cancer. 2018. (serial online), [cited 2018 August. 22]. Available from: http://www.who.int/cancer/ prevention/diagnosis-screening/cervical-cancer/en

3. Azizah, Sofian A, \& Suyanto. Gambaran kualitas hidup pasien kanker serviks yang menjalani radioterapi di RSUD Arifin Achmad Provinsi Riau Periode 2011-2013 [The quality of life of cervical cancer patients with radiotherapy at Arifin Achmad Hospital, Riau Province, 2011-2013]. Jurnal Online Mahasiswa. 2014;1(2):1-14.

4. Sitio R, Suza DE, \& Nasution SS. Kualitas hidup pasien kanker serviks: pengalaman pasien suku Batak Toba [The quality of life of cervical cancer patients: the experiences of Batak Toba patients]. Idea Nursing Journal. 2016;VII(3):9-17.

5. Manju HK \& Basarajavappa. Role of emotion regulation in quality of life. The International Journal of Indian Psychology. 2016; 4(1), 81.

6. Mustafa K, Nashori HF, \& Astuti YD. The emotion regulation training to improve quality of life in patients with hypertension. Indonesian Journal of Medicine and Health. 2016;7(4), 143-150.

7. Smyth JM \& Arigo D. Recent evidence support emotion-regulation interventions for improving health in at-risk and clinical populations. Current Opinion in Psychiatry. 2009. (serial online), [cited 2018 June.2]. Available from:URL:http://doi.org/10.1097/YCO. ob013e3283252d6d

8. Fitriana NA \& Ambarini TK. Kualitas hidup pada penderita kanker serviks yang menjalani pengobatan radioterapi [The quality of life of cervical cancer patients with radiotherapy]. Jurnal Psikologi Klinis dan Kesehatan Mental. 2012; 1(02):123-9.

9. Banovcinova L, Baskova M. Role of the family, friends and significant others in providing social support and enhancing quality of life in cancer patients. SHS Web of Conferences. 2016;30.

10. Nazik E, Nazik H, Ozdemir F, Soydan S. Social support and quality of life in Turkish patients with gynecologic cancer. Asian Pacific Journal of Cancer Prevention. 2014;15(7), 3081-3086.

11. Wang Y, Zhu L, Yuan F, Kang L, Jia Z, Chen D, et al. The relationship between social support and quality of life: evidence from a prospective study in Chinese patients with esophageal carcinoma. Iranian Journal of Public Health. 2015; 44(12):1603-12.

12. Sanglah General Hospital. Laporan tahunan Poliklinik Kebidanan tahun 2016 [Yearly report on Obstetric and Gynecology Polyclinic year 2016]. Denpasar.

13. Zainab R. Hubungan dukungan keluarga dengan kualitas hidup pasien kanker payudara yang menjalani kemoterapi di RSUD Dr. Zainoel Abidin Banda Aceh [The association of family support and quality of life of breast cancer patients with chemotherapy in Dr. Zainoel Abidin Hospital, Banda
Aceh]. Electronic Thesis and Dissertations. 2014. (serial online), [cited 2018 January.22]. Available from: http://etd. unsyiah.ac.id/ baca/ index.php? id=11969\&page $=1$

14. Gross JJ, John OP. Individual differences in two emotion regulation processes: implications for affect, relationships, and well-being. Journal of Personality and Social Psychology. 2003; 85(2):348-62.

15. Friedman MM, Bowden VR, Jones EG. Buku ajar keperawatan keluarga: riset, teori, dan praktik [Teaching book on family nursing: research, theory and practice]. Jakarta: EGC; 2010 .

16. Noviyani R, Tunas K, Indrayathi A, Budiana NG. Validity and reliability of EORTC QLQ C-30 questionnaire in assessing quality of life of gynecological cancer patients in Sanglah Hospital Denpasar. Jurnal Farmasi Klinik Indonesia. 2016; 5(2), 106-114.

17. Erfina. Pengalaman spiritual perempuan dengan kanker serviks di RSUPN dr. Cipto Mangunkusumo Jakarta (tesis) [Spiritual experiences of women with cervical cancer in $\mathrm{dr}$. Cipto Mangunkusumo Hospital Jakarta (thesis)]. Jakarta: Universitas Indonesia; 2010.

18. Husni M, Romadoni S, Rukiyati D. Hubungan dukungan keluarga dengan kualitas hidup pasien kanker payudara di Instalasi Rawat Inap Bedah RSUP Dr. Mohammad Hoesin Palembang tahun 2012 [The association of family support and quality of life of breast cancer patients in Surgery Inpatient Wards Dr. Mohammad Hoesin Hospital Palembang year 2012]. Jurnal Keperawatan Sriwijaya. 2012; 2(2355):77-83.

19. Adriani RB, Martono, Sulistyowati EC. The effect of depression on the quality of life of patient with cervical cancer at Dr. Moewardi Hospital in Surakarta. Indonesian Journal of Medicine. 2016; 1(2): 121-128.

20. Khalil J, Bellefqih S, Sahli N, Afif M, Elkacemi H, Elmajjaoui S, Kebdani T and Benjaafar N. Impact of cervical cancer on quality of life: beyond the short term (Results from a single institution). Gynecologic Oncology Research and Practice. 2015; 2:7.

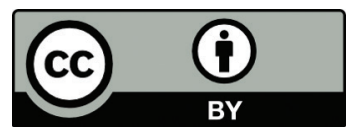

This work is licensed under a Creative Commons Attribution 